\title{
Carbon sequestration potential of the stands under the Grain for Green Program in Yunnan Province, China
}

\author{
Xiangang Chen ${ }^{a, b, c, d, *}$, Xiaoquan Zhang ${ }^{e}$, Yiping Zhang ${ }^{a}$, Chengbin Wan ${ }^{f}$ \\ ${ }^{a}$ Xishuangbanna Tropical Botanical Garden of CAS, Kunming 650223, China \\ ${ }^{\mathrm{b}}$ Research Center for Eco-Environmental Sciences of CAS, Beijing 100085, China \\ ${ }^{\mathrm{c}}$ Graduate School of CAS, Beijing 100039, China \\ ${ }^{\mathrm{d}}$ Department of Environmental Science and Engineering of SWFC, Kunming 650224, China \\ e Institute of Forest Ecology, Environment and Protection, CAF, Beijing 100091, China \\ ${ }^{\mathrm{f}}$ Department of Foreign Languages of SWFC, Kunming 650224, China
}

\section{A R T I C L E I N F O}

\section{Article history:}

Received 31 January 2008

Received in revised form 26 June 2008

Accepted 9 July 2008

\section{Keywords:}

Carbon sequestration

Grain for Green Program

Yunnan Province

\begin{abstract}
A B S T R A C T
The carbon sequestration potential in living biomass and soil organic matter under the Grain for Green Program (GGP) in Yunnan Province, one of the most important target provinces of the GGP in China, was estimated in this paper using empirical curves and factors. The area of tree species planted during 20002007 was collected, and four scenarios for the annual area of GGP-stands to be planted during 20082010 and harvest options were schemed. Empirical growth curves for different tree species were developed based on data about the growth of existing plantation in Yunnan Province from National Forestry Inventory, and were used for the estimation of the carbon stocks in the tree biomass pools by incorporating with basic wood density, biomass expansion factors and carbon fraction. Empirical factors were introduced to estimate the stock change in soil organic carbon (SOC) under the GGP. The results show that the carbon stock in the GGP-stands in Yunnan Province will increase by 12.47412.608 TgC, 33.016-35.161 TgC, 38.119-47.100 TgC, 43.057-53.626 TgC and 49.918-56.621 by the year 2010, 2020, 2030, 2040 and 2050, respectively. The annual carbon stock change in the GGP-stands will peak at 2.342-2.536 TgC per year in 2013, followed by a gradual decrease. The estimated potential carbon sequestration by GGP-stands amounts to $10.82-12.27 \%$ of the carbon stocks of forest ecosystems in Yunnan province in the 1990s.
\end{abstract}

(c) 2008 Elsevier B.V. All rights reserved.

\section{Introduction}

With an increasing concern for global climate changes resulting from more and more anthropogenic greenhouse gas, protecting carbon stocks in the existing forests and getting the new carbon stocks through afforestation and reforestation have become the important measures to enhance the carbon sequestration capacity in the terrestrial ecosystems and mitigate the increasing carbon dioxide concentration in the atmosphere. The Grain for Green Program (GGP) was initiated in China in 1999, with an aim to control soil erosion and combat desertification by restoring forest vegetation on degraded/decertified barren land and cropland with slope

\footnotetext{
* Corresponding author at: Institute of Forest Ecology, Environment and Protection, CAF, Wan Shou Shan, Beijing 100091, China.

E-mail address: xiaoquan@caf.ac.cn (X. Zhang).
}

gradient over $25^{\circ} .32$ million hectares (Mha) of lands, including 14.67 Mha of croplands and 17.33 Mha of barren lands, were planned to be planted under the GGP during the period of 19992010. $24,243,468$ ha of lands, involving $9,264,135$ ha of croplands and $14,979,333$ ha of barren lands, had been planted by the end of the year 2007 (Fig. 1) (refer to the Annual Reports on the Development of Chinese Forestry (1999-2007) edited by State Forestry Administration, PR China). It is expected that 7,756,532 ha of lands involving 5,402,532 ha of eligible croplands and 2,354,000 ha of barren lands will be planted by the year 2010 (RGCFSDS, 2002). Located in the southwest corner of China, Yunnan Province is one of the most important provinces under the GGP. After a pilot phase (2000-2001), the GGP has been implemented almost throughout Yunnan Province involving 126 counties. By the end of the year 2007, 943,125 ha of lands has been planted under GGP including 355,556 ha of eligible croplands and 587,569 ha of barren lands (Table 1 and Fig. 2) (refer to the Annual Provincial Verification 


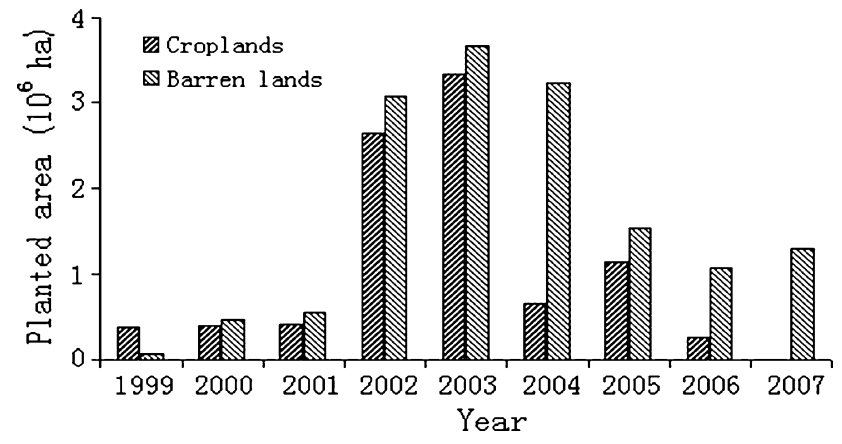

Fig. 1. Planted area under the Grain for Green Program in China.

Reports on Grain for Green Program in Yunnan (2000-2007) edited by Yunnan Provincial Forestry Department, PR China). It accounts for $3.89 \%$ of the national GGP-lands (3.84\% of eligible croplands and $3.92 \%$ of barren lands under the GGP respectively) (Chen, 2002; $\mathrm{Li}$, 2004).

The large scale of afforestation under the GGP will establish a large amount of new forest vegetation to enhance carbon sequestration capacity in terrestrial ecosystems in China. So far a lot of studies have touched upon the carbon stocks as well as their changes in one or more parts of the forest ecosystems in the world or some countries or regions (Grigal and Ohmann, 1992; Birdsey and Plantinga, 1993; Dixon et al., 1994; Zhou et al., 2000; Fang et al., 2001; Wang et al., 2001; Like et al., 2000; Zhao and Zhou, 2004; Liu and Lei, 2005), including some Chinese provinces or regions (Zhang et al., 2002; Cao et al., 2002; Jiao and Hu, 2005). Yet few research on the carbon sequestration potential of such a largescale program of tree planting as Chinese GGP. A paper published in the year 2006 was the precursor of this kind and it dealt with estimating the carbon sequestration potential after afforestation on marginal croplands in U.S. (Niu and Duiker, 2006). The objective of this study is to estimate the carbon sequestration potential under GGP in Yunnan Province by means of calculating the carbon stock changes of GGP-stands, and to provide a method for further estimating the potential of national GGP-stands in the long run.

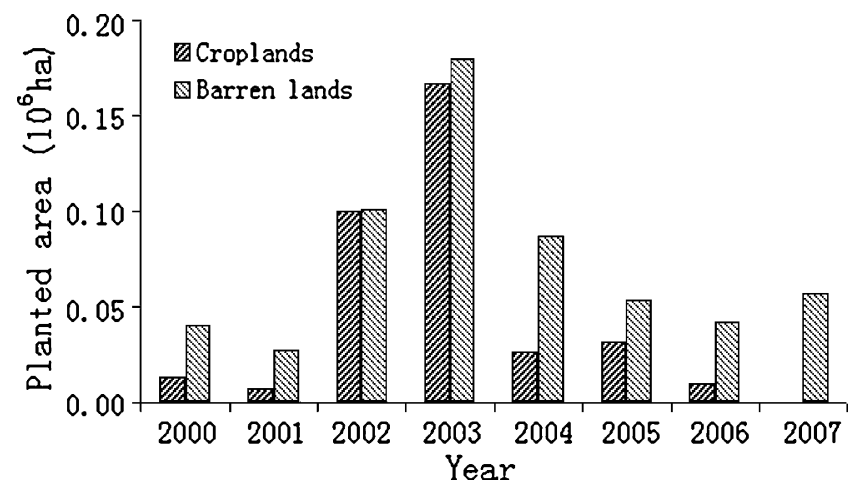

Fig. 2. Planted area under the Grain for Green Program in Yunnan Province.

\section{Materials and methods}

\subsection{Area of tree species of the GGP-stands in Yunnan Province}

The planted area for each tree species under the GGP in Yunnan Province from 2000 to 2007 are collected from Yearly Provincial Verification Reports on the Grain for Green Project in Yunnan (20002007) edited by Yunnan Provincial Forestry Department, PR China (Table 1). Based on the national target of the GGP-stands up to the year 2010 (RGCFSDS, 2002) and the area proportion of the provincial GGP-stands to the national GGP-stands in the years from 2000 to 2007 , it is predicted that 301,746 ha of lands will be planted under the GGP in Yunnan Province in the years from 2008 to 2010, including 113,758 ha of eligible croplands and 187,986 ha of barren lands. The annual planting area of GGP-stands varied significantly in the past and peaked in the year 2003 (346,894 ha). After a pilot phase, farmers' enthusiasm for planting GGP-stands increased rapidly during 2002-2003 due to an encouraging policy. From 2004 to 2007, government gradually cut down the subsidized area of GGPstands in order to enhance the quality of grown and growing GGPstands, and the annual area of GGP lands range from 52,468 to 85,400 ha during 2005-2007. Based on the governmental planned goal and the actual situation in last 3 years, the annual area to be planted from 2008 to 2010 is schemed as following two scenarios:

Table 1

Area planted and to be planted for each tree species/species group under the Grain for Green Program in Yunnan Province (ha)

\begin{tabular}{|c|c|c|c|}
\hline Species/species group & $\begin{array}{l}\text { Planted area 2000-2007 } \\
\text { (total area) }\end{array}$ & $\begin{array}{l}\text { Scenario A 2008-2010 } \\
\text { (annual area) }\end{array}$ & $\begin{array}{l}\text { Scenario B 2008-2010 } \\
\text { (annual area) }\end{array}$ \\
\hline Pinus armandi & $77,369.8$ & $8,051.9$ & $5,319.6$ \\
\hline P. yunnanensis & $65,193.2$ & $6,784.6$ & $4,482.4$ \\
\hline Larix gmelini & $1,558.6$ & 162.2 & 107.2 \\
\hline Pinus kesiya var. langbianensis & $32,873.5$ & $3,421.1$ & $2,260.2$ \\
\hline Cunninghamia laceolata & $26,257.7$ & $2,732.6$ & $1,805.4$ \\
\hline Picea asperata & $1,710.2$ & 178.0 & 117.6 \\
\hline Cryptomeria fortunei & $8,131.5$ & 846.2 & 559.1 \\
\hline Abies spp. & $3,543.1$ & 368.7 & 243.6 \\
\hline Keteleeria spp. & 61.0 & 6.3 & 4.2 \\
\hline Platycladus orientalis & $25,467.2$ & $2,650.4$ & $1,751.0$ \\
\hline Other conifer & $10,019.9$ & $1,042.8$ & 688.9 \\
\hline Cinnamomum camphora & 272.6 & 28.4 & 18.7 \\
\hline Quercus spp. & $2,287.9$ & 238.1 & 157.3 \\
\hline Hardwood & $62,645.7$ & $6,519.5$ & $4,307.2$ \\
\hline Eucalyptus spp. & $74,116.1$ & $7,713.3$ & $5,095.9$ \\
\hline Sassafras tzumu & $1,910.6$ & 198.8 & 131.4 \\
\hline Populus deltoides & $2,722.5$ & 283.3 & 187.2 \\
\hline Aluerites fordii & $3,346.6$ & 348.3 & 230.1 \\
\hline Betula spp. & $32,828.4$ & $3,416.5$ & $2,257.1$ \\
\hline Softwood & $267,076.2$ & $27,794.6$ & $18,363.0$ \\
\hline Unidentified species & $69,541.9$ & $7,237.2$ & $4,781.4$ \\
\hline Total & $943,122.7$ & $98,150.8$ & $64,844.9$ \\
\hline
\end{tabular}


(1) Scenario A: Evenly allocating the annual area to be planted in the following 3 years corresponding to the planed goal (Table 1);

(2) Scenario B: Equally allocating the annual area to be planted in the following 3 years corresponding to the average annual area in the past 3 years (2005-2007) (Table 1 ).

The planting area for each species in next 3 years is predicated based on the planted area proportion of each species to all the species under the GGP in Yunnan Province (Table 1).

\subsection{Methods for estimating carbon stock changes}

The carbon sequestration potential of GGP is expressed as the carbon stock changes in the tree biomass and soil organic matter of GGP-stands. Although carbon stock in dead organic matter (litter and dead wood) is subjected to increase after afforestation or reforestation on cropland or barren land, its changes were not estimated in this paper due to unavailable data and lower change rate relative to living tree biomass.

\subsection{Carbon stocks in living tree biomass}

The carbon stocks change method was adopted for estimating carbon stocks in living tree biomass of GGP-stands, using formula (1):

$\mathrm{CST}_{i}=\sum_{j} \sum_{k} S_{j k} V_{i j k} \mathrm{WD}_{j} \mathrm{BEF}_{j} \mathrm{CF}_{j}$

where $\mathrm{CST}_{i}$ corresponds to carbon stocks $(\mathrm{MgC})$ in living tree biomass in target year $i, S_{j i}$ represents the area (ha) of species $j$ planted or to be planted in year $k, V_{i j k}$ indicates stand volume per hectare $\left(\mathrm{m}^{3} \mathrm{ha}^{-1}\right)$ in target year $i$ for species $j$ planted in year $k, W D_{j}$ is the basic wood density $\left(\mathrm{Mg} \mathrm{m}^{-3}\right)$ of species $j, \mathrm{BEF}_{j}$ is a biomass expansion factor (dimensionless) for conversion of stem biomass to stand biomass (including stems, branches, foliages and roots) for species $j, \mathrm{CF}_{j}$ is carbon fraction $\left(\mathrm{MgC} \mathrm{Mg}^{-1}\right)$ of species $j$.

The stand volume of established plantations varies with tree species, site conditions, age class and forest management. Due to lack of available data, it is difficult to estimate the volume growth in terms of site conditions and forest management practices. However, the National Forestry Inventory (NFI) conducted once every 5 years since 1970 s provides stand volumes corresponding to five age classes of some tree species/species group of plantations in Yunnan Province (CSIMFR and YPFD, 1993,1998,2003). The NFI data can represent an average growth value of the stand volume for different site conditions and forest management practices. The stand volume of different tree species of plantations was fitted against age class using SPSS:

$V_{i j k}=a(1-\exp (-b A))^{c}$

where $A$ represents stand age, $A=i-k ; a, b$ and $c$ are parameters to be fitted. The fitted growth curves (Fig. 3 ) were used to estimate the stand volume of different species/species group of the GGPstands in the target year $i$. Except for tree species with specific growth curve, the curves corresponding to conifer, broadleaves and mixed conifer and broadleaves were respectively used for other coniferous species, broadleaf trees and mixed tree species. Shrub, rattan and grass planted under GGP are not included in the estimation due to negligible biomass.

The biomass expansion factor (BEF) and basic wood density (WD) used in the estimation are from the China initial national communication (Table 2) (IFEEP, 2004). Carbon fractions (CF) are derived from literature reviews (Table 2) (SFAPRC, 2001).
Table 2

Values of wood density (WD), biomass expansion factor (BEF), carbon fraction (CF) and minimum rotation (MR) for different tree species

\begin{tabular}{|c|c|c|c|c|}
\hline Species/species groups & $\begin{array}{l}\text { WD } \\
\left(\mathrm{Mg} \mathrm{m}^{-3}\right)\end{array}$ & $\begin{array}{l}\text { BEF } \\
\text { (whole tree) }\end{array}$ & $\mathrm{CF}$ & $\begin{array}{l}\text { MR } \\
\text { (years) }\end{array}$ \\
\hline L. gmelini & 0.49 & 1.74 & 0.51 & 61 \\
\hline P. armandi & 0.396 & 2.29 & $0.50^{\mathrm{a}}$ & 51 \\
\hline P. yunnanensis & 0.483 & 2.04 & 0.54 & 51 \\
\hline P. kesiya var. langbianensis & 0.454 & 1.83 & $0.50^{\mathrm{a}}$ & 51 \\
\hline Abies spp. & 0.366 & 2.12 & 0.49 & 61 \\
\hline P. asperata & 0.342 & 2.12 & 0.51 & 101 \\
\hline Keteleeria spp. ${ }^{\text {b }}$ & 0.448 & 2.23 & $0.50^{\mathrm{a}}$ & 51 \\
\hline C. fortunei & 0.294 & 1.91 & $0.50^{\mathrm{a}}$ & 36 \\
\hline C. laceolata & 0.307 & 1.92 & 0.49 & 36 \\
\hline P. orientalis & 0.478 & 2.11 & 0.5 & 101 \\
\hline Mixed conifer stand & 0.405 & 2 & 0.52 & - \\
\hline C. camphora & 0.46 & 1.89 & 0.49 & 71 \\
\hline Quercus spp. & 0.676 & 2.09 & 0.5 & 71 \\
\hline Hardwood & 0.598 & 2.34 & $0.50^{\mathrm{a}}$ & 71 \\
\hline Betula spp. & 0.541 & 1.62 & 0.5 & 51 \\
\hline S. tzumu & 0.477 & 2.49 & $0.50^{\mathrm{a}}$ & 26 \\
\hline Eucalyptus spp. & 0.578 & 1.65 & $0.50^{\mathrm{a}}$ & 26 \\
\hline P. deltoids & 0.378 & 2.16 & 0.51 & 26 \\
\hline A. fordii & 0.239 & 3.69 & $0.50^{\mathrm{a}}$ & 26 \\
\hline Softwood & 0.443 & 2.5 & $0.50^{\mathrm{a}}$ & 26 \\
\hline Mixed broadleaf trees & 0.482 & 1.95 & 0.44 & 51 \\
\hline
\end{tabular}

a Generally used value.

b Substituted by the value of similar species.

Over 95\% of forests established under the GGP in Yunnan Province belongs to the so-called Ecological Service Forests (noncommercial plantations) (refer to the Annual Provincial Verification Reports on Grain for Green Grogram in Yunnan (2000-2007) edited by Yunnan Provincial Forestry Department, PR China) (Chen, 2002). According to Technical Regulations for Ecological Service Forest (SFAPRC, 2001; SCPRC, 2002), these forests are not allowed to harvest until over mature. The minimum rotation for major species of ecological service forest are listed in Table 3. However, it is possible that the forests planted or to be planted under GGP will never be harvested because the target lands are usually located at the mountainous areas. Therefore we further develop Scenario A and Scenario B as follows:

Scenario A-1: Scenario A without harvest;

Scenario A-2: Scenario A with harvest at the minimum harvest age;

Table 3

Carbon stock changes of the stands under the Grain for Green Program in Yunnan Province in the next 50 years $(\mathrm{TgC})$

\begin{tabular}{|c|c|c|c|c|c|}
\hline & \multicolumn{5}{|l|}{ Year } \\
\hline & 2010 & 2020 & 2030 & 2040 & 2050 \\
\hline \multicolumn{6}{|l|}{ Scenario A-1 } \\
\hline Living biomass & 8.798 & 25.595 & 32.892 & 34.776 & 35.307 \\
\hline Soil organic carbon & 3.810 & 9.566 & 14.208 & 18.849 & 21.314 \\
\hline Total & 12.608 & 35.161 & 47.100 & 53.626 & 56.621 \\
\hline \multicolumn{6}{|l|}{ Scenario A-2 } \\
\hline Living biomass & 8.798 & 25.595 & 27.405 & 27.541 & 32.814 \\
\hline Soil organic carbon & 3.810 & 9.566 & 14.208 & 18.849 & 21.314 \\
\hline Total & 12.608 & 35.161 & 41.613 & 46.391 & 54.128 \\
\hline \multicolumn{6}{|l|}{ Scenario B-1 } \\
\hline Living biomass & 8.721 & 24.057 & 30.380 & 32.007 & 32.468 \\
\hline Soil organic carbon & 3.753 & 8.959 & 13.225 & 17.492 & 19.614 \\
\hline Total & 12.474 & 33.016 & 43.606 & 49.499 & 52.083 \\
\hline \multicolumn{6}{|l|}{ Scenario B-2 } \\
\hline Living biomass & 8.721 & 24.057 & 24.894 & 25.565 & 30.304 \\
\hline Soil organic carbon & 3.753 & 8.959 & 13.225 & 17.492 & 19.614 \\
\hline Total & 12.474 & 33.016 & 38.119 & 43.057 & 49.918 \\
\hline
\end{tabular}



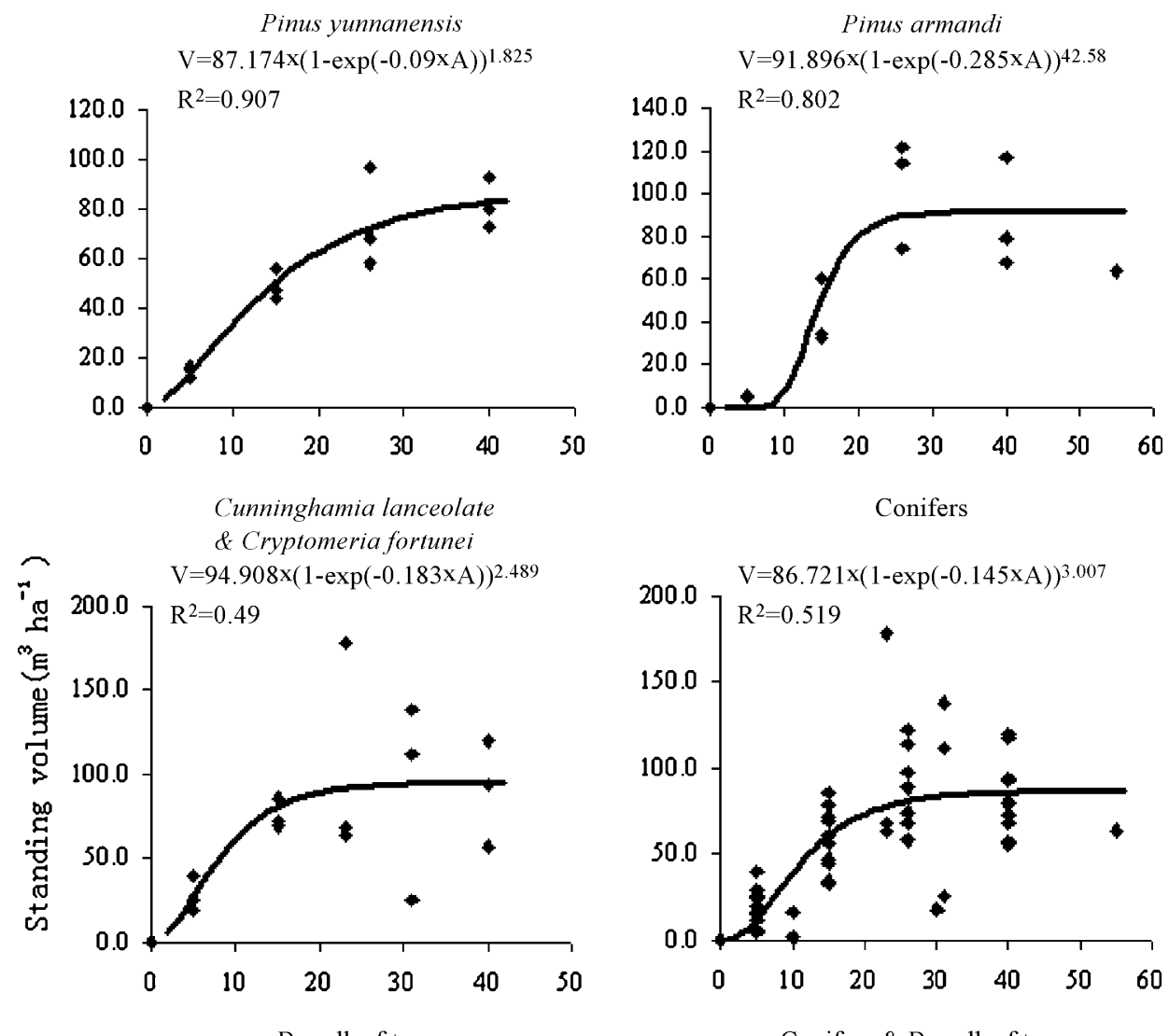

Broadleef tree

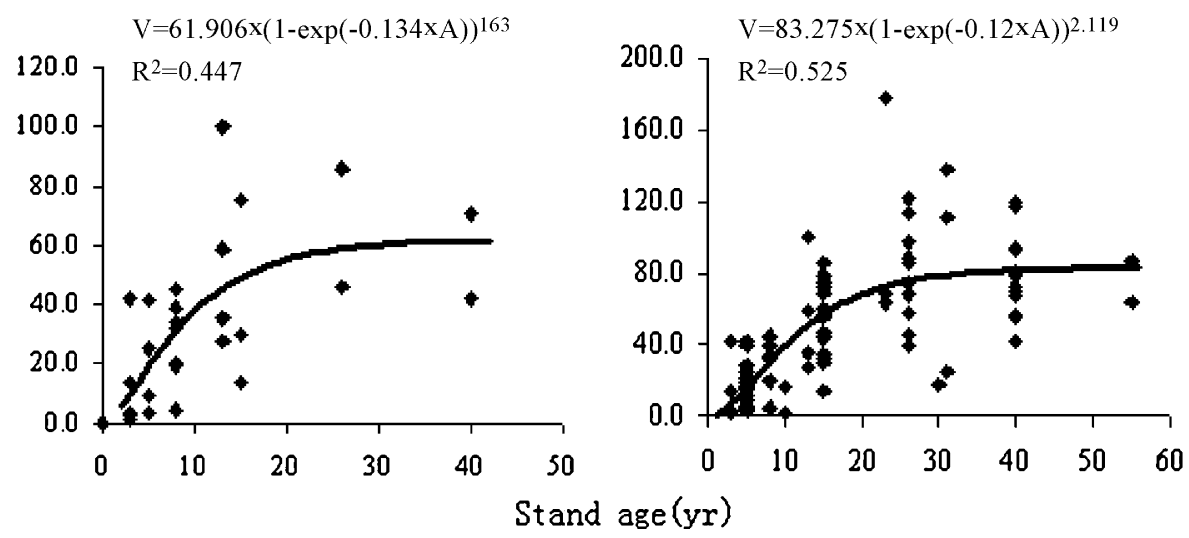

Fig. 3. Fitted growth curve for different species/species-groups of plantations in Yunnan Province.

Scenario B-1: Scenario B without harvest;

Scenario B-2: Scenario B with harvest at the minimum harvest age.

For scenarios with harvest, it is assumed that all harvested biomass will decompose immediately and all harvested lands will be regenerated immediately after harvest and the aboveground part of all cut trees will be cleared out.

\subsubsection{Carbon stock changes in soil organic matter}

Soil is likely to be a potential sink of carbon following afforestation in the long term, however, stock changes of soil organic carbon (SOC) following afforestation vary significantly with land use/cover types before planting and other bio-physical conditions (Post and Kwon, 2000; Paul et al., 2002), and the changes are usually non-linear over time (Bateman and Lovett, 2000; Post and Kwon, 2000; Paul et al., 2002; Paul et al., 2003).

The GGP-lands, similar to the marginal agricultural land in U.S. (Niu and Duiker, 2006), are largely degraded croplands/barrenlands that generally have a low initial SOC stock. Intensive site and soil preparation that usually results in significant soil erosions is not allowed and original vegetation is requested to be maintained as much as possible by the GGP (refer to the Annual Provincial Verification Reports on Grain for Green Grogram in Yunnan (20002007) edited by Yunnan Provincial Forestry Department, PR China). Therefore, SOC does not likely decrease after the planting of the GGP lands although Paul et al. (2002) summarized an initial SOC loss after afforestation on croplands. Given this, factors for SOC stock changes from Niu and Duiker (2006) were used for our estimation. The SOC stock changes were then estimated by the 


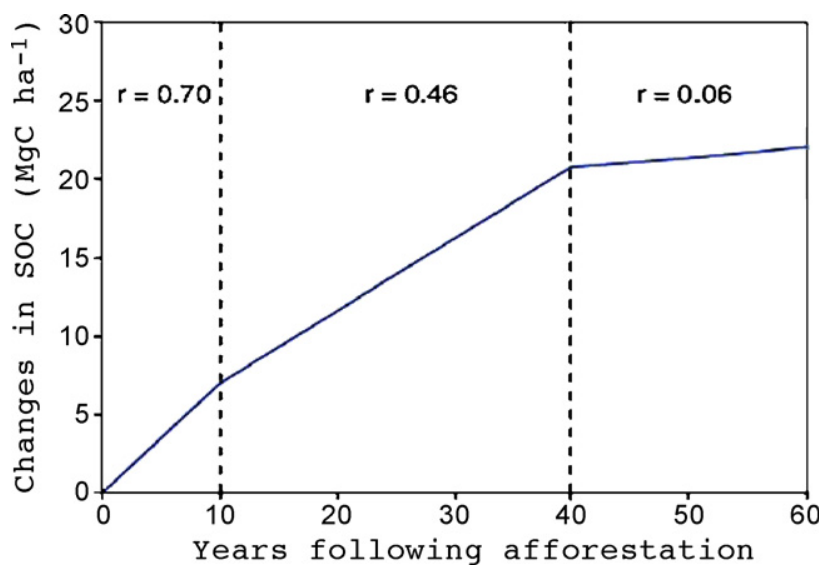

Fig. 4. Factors in changes of soil organic carbon (SOC) over time (Niu and Duiker, 2006); $r$ represents the SOC change rate.

formula:

$\operatorname{SOCC}_{i}=\sum_{j} \sum_{k} r(i-k) S_{j k}$

where $\mathrm{SOCC}_{i}$ corresponds to the SOC stock change $(\mathrm{MgC})$ in SOC pool in target year $i, S_{j k}$ represents the area (ha) of species $j$ planted or to be planted in year $k, \gamma$ represents the factor of SOC stock change (MgC ha ${ }^{-1}$ year $^{-1}$ ) (Fig. 4).

\section{Results}

\subsection{Carbon sequestration potential of GGP-stands}

Under the four scenarios, the carbon stock change of the GGPstands in Yunnan Province is expected to be 12.474-12.608 TgC, 33.016-35.161 TgC, 38.119-47.100 TgC, 43.057-53.626 TgC and 49.918-56.621 TgC by the year 2010, 2020, 2030, 2040 and 2050, respectively. Among them, the carbon sequestration in living tree biomass are 8.721-8.798 TgC, 24.057-25.595 TgC, 24.894$32.892 \mathrm{TgC}, \quad 25.565-34.776 \mathrm{TgC}$ and $30.304-35.307 \mathrm{TgC}$, and the SOC stock changes are $3.753-3.810 \mathrm{TgC}, 8.959-9.566 \mathrm{TgC}$, 13.225-14.208 TgC, $17.492-18.894 \mathrm{TgC}$ and $19,614-21.314 \mathrm{TgC}$, correspondingly (Table 3 ). The SOC stock change accounts for $27.14-40.63 \%$ of the carbon stock change of the GGP-stands. The carbon stock change of the GGP-stands for Scenario B is less than that for Scenario A. After harvesting the carbon stock change of the GGP-stands for Scenario A-2 and Scenario B-2 are smaller than that for Scenario A-1 \& Scenario B-1, correspondingly (Fig. 5). In 2012, the annual carbon stock change of GGP-stands will peak at 2.536 $\operatorname{TgC}$ year $^{-1}$ for Scenario A-1 and A-2 and $2.342 \mathrm{TgC}_{\text {year }}{ }^{-1}$ for Scenario B-1 and B-2, followed by a gradual decrease (Fig. 6). Particularly, there are $2.601 \mathrm{TgC}_{\text {year }}^{-1}$ and $2.691 \mathrm{TgC}^{-1} \mathrm{year}^{-1}$ of the maximum net emission in 2030 for Scenario A-2 and Scenario B-2 due to harvesting. The carbon sequestration potential of the GGP-stands on croplands amounts to $39.84-40.24 \%$ of the total potential of GGP-stands in 2010, 36.58-38.65\% in 2020, 34.13$38.31 \%$ in $2030,35.62-38.34 \%$ in 2040 and $35.40-38.19 \%$ in 2050 , respectively. Most of the carbon sequestration occurs in the period 2005-2025 (Fig. 6).

\subsection{CSP of GGP-stands for the major species}

The area planted with seven major tree species (e.g., Pinus armandi, Pinus yunnanensis, Pinus kesiya var. langbianensis, Platycladus orientalis, Cunninghamia laceolata, Eucalyptus spp. and Betula spp.) accounted for $43.5 \%$ of the total area of established GGP-stands in Yunnan Province (Table 1) (refer to the Annual Provincial Verification Reports on Grain for Green Grogram in Yunnan (2000-2007) edited by Yunnan Provincial Forestry Department, PR China) (Chen, 2002; Li, 2004). The carbon sequestration potential of the GGP-stands of these seven major tree species in Yunnan Province is expected to account for 43.27$50.56 \%$ of the total GGP-stands for during 2020-2050. In particular,

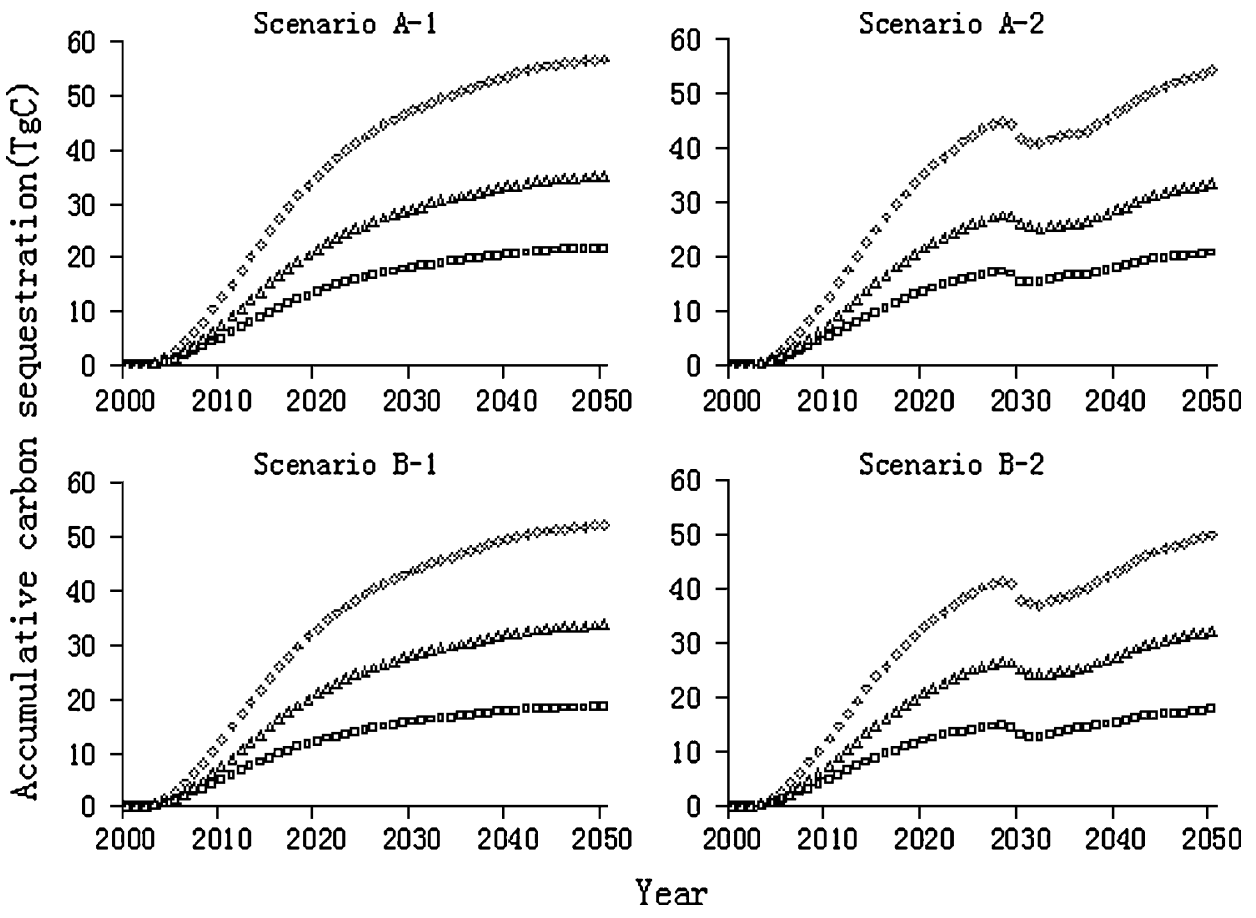

Fig. 5. Carbon sequestration potential of the Grain for Green Program in Yunnan Province. 

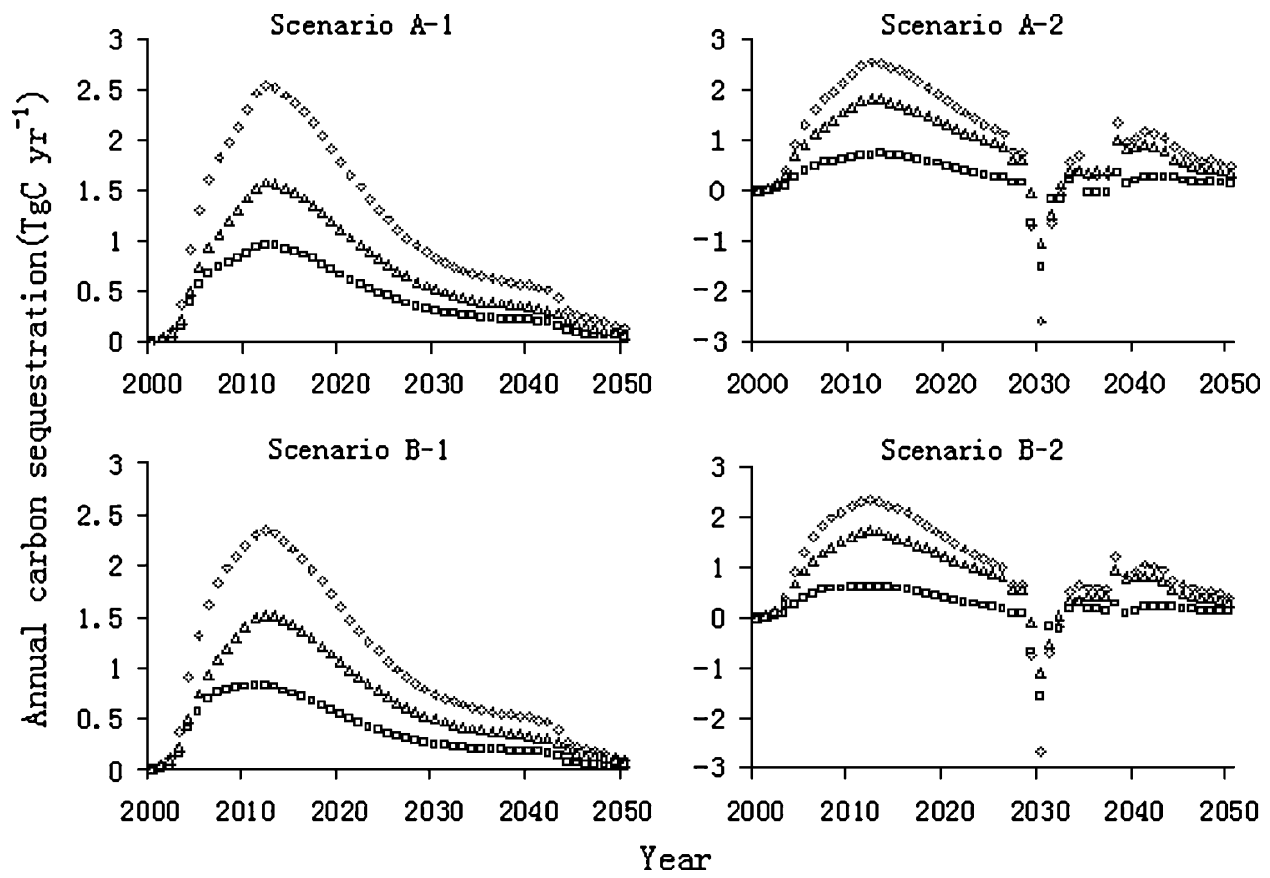

Fig. 6. Annual carbon sequestration potential of the Grain for Green Program in Yunnan Province.

P. armandi, P. yunnanensis and Eucalyptus spp. are the most popular tree species under GGP. By 2010, 2020, 2030, 2040 and 2050, the carbon sequestration potential of $P$. armandi stands will be 0.436-0.442, 3.505-3.624, 5.399-5.829, 5.965-6.468 and 6.175$6.715 \mathrm{TgC}$, respectively; for $P$. yunnanensis stands it will be $1.111-1.121,2.977-3.166,4.151-4.472,4.879-5.279$ and 5.205$5.655 \mathrm{TgC}$, respectively; and for Eucalyptus spp. stands it will be $1.172-1.187,2.822-3.024,3.612-3.905$ (2.615-2.907), 4.127$4.472(2.950-3.133)$ and $4.374-4.755$ (4.030-4.361) TgC, respectively (the data in the brackets is the result when any harvesting happens) (Fig. 7).

\section{Discussion}

\subsection{Applicability of growth curves}

The growth curves applied play a crucial role in the estimation of the carbon stocks in the living tree biomass. In this paper the growth curves, fitted by the standing volume of plantations established in various places with relatively poorer site conditions as the lands with good site conditions were almost reclaimed to farmlands in Yunnan Province in the past, represent the mean growth under the diverse climate, site conditions as
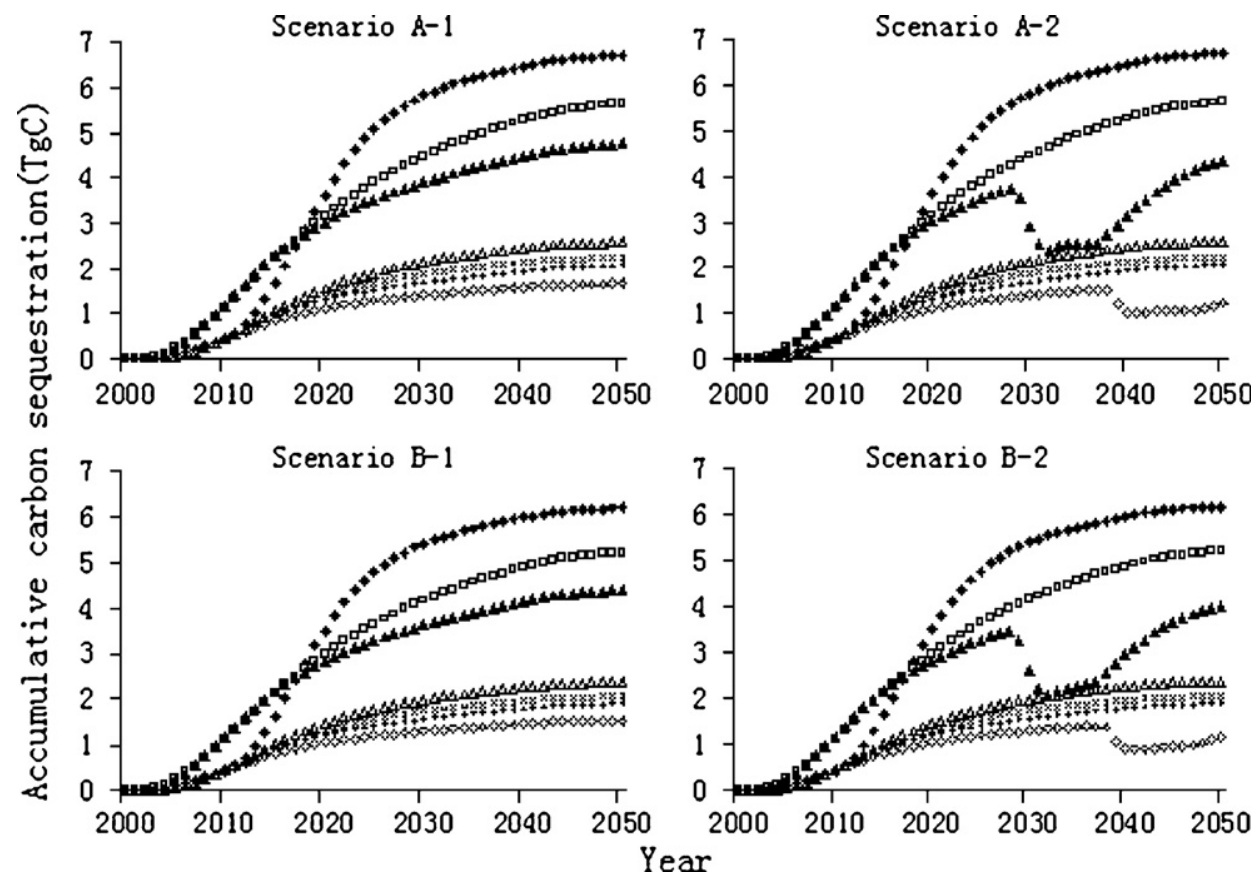

Fig. 7. Carbon sequestration potential for seven major tree species under the Grain for Green Program in Yunnan Province. 
well as management practices. Since the GGP-stands are also the plantations with the different climate and site conditions, using these growth mean curves may lead to overestimation of some areas with worse site conditions or underestimation of other areas with better site conditions. Therefore, as a whole, it is feasible to use these growth curves to estimate the growth of GGP-stands given that the growth curves for different site conditions are unavailable.

\subsection{Role of the carbon sequestration of GGP-stands}

In Yunnan Province, the area of GGP-lands accounts for $2.45 \%$ of the total lands, and is equal to $6.24 \%$ of the forested lands and $37.29 \%$ of plantations. The carbon stock change of the GGPstands by the year 2050 will be up to $10.82-12.27 \%$ of the carbon stocks of the forest vegetation in Yunnan Province in the1990s (461.43 TgC) (Zhao and Zhou, 2004), varying with different scenarios.

\subsection{Harvest wood product}

The harvest biomass was assumed to decompose immediately in our estimation. However, a majority of logged trees will be transformed to wood products which have certain lifetime. Within their lifetime, it is reasonable to count the carbon in the harvest wood products. Skog and Nicholson (2000) reported that the carbon stocks of these harvest wood products accounts for $14.1 \%$ of that of the total trees logged, yet Niu and Duiker (2006) argued that the proportion should be up to $32 \%$. The carbon in the harvest wood products is not included in our estimation due to lack of data on harvest wood product.

\subsection{Issue of carbon baseline}

The carbon sequestration of afforestation and refforestation often involves the issues of carbon baseline and carbon leakage (IPCC, 2000; Willems, 2000; Lazams et al., 2001; UNFCCC, 2001, 2003). The baseline refers to the change of the carbon stocks within the project boundary in the absence of the project (Willems, 2000). The Chinese GGP aims to restore forest vegetation on some croplands and barren mountainous lands. The croplands for GGP are restricted to desertified lands or lands with slope gradient over $25^{\circ}$. In the absence of the GGP, these lands would continue to degrade or at least in a steady state. So the carbon baseline of the GGP-stands can be conservatively assumed to be zero

\subsection{Issue of carbon leakage}

The carbon leakage means a countable carbon emission resulting from a project and occurring outside a project boundary (UNFCCC, 2003). The croplands and barren lands used for GGP usually have a very low productivity. These lands are often situated in the remote mountainous areas where there are usually less populated and people have enough croplands for food. Meanwhile, Chinese government provides food and/or cash subsidies for farmers who have planted trees on their croplands eligible for GGP, which can compensate these farmers for the loss of food due to the GGP. Moreover, government also provides farmers with seedlings for tree planting and transfers the ownership of the wood and non-wood forest products to these farmers (SCPRC, 2002). Besides, the major work of the GGP in Yunnan Province is carried out manually instead of mechanically. Therefore, the leakage of the GGP is unlikely to occur and is nil.

\section{Conclusion}

The GGP will contribute significantly to the carbon sequestration in Yunnan Province in the next 50 years. Scenario A is more optimistic, under which the governmental goal is expected to be fulfilled, and the planting area (including the area for growing grass) of the GGP will be up to 1.238 Mha and the carbon sequestration of GGP-stands will be up to $54.128-56.621 \mathrm{TgC}$ by the year 2050. Scenario B are more likely under which the planting area of the GGP will be up to 1.139 Mha and the carbon sequestration of GGP-stands will be up to 49.918-52.083 TgC by the year 2050. The carbon sequestration of the seven major tree species of GGP-stands accounts for 43.27-50.56\% of that of the total tree species of GGP-stands. The total carbon sequestration of GGP-stands by 2050 amount to $10.82-12.27 \%$ of the carbon stocks of the forest vegetation in Yunnan Province in the 1990s.

To get more accurate data about carbon sequestration of GGPlands, following components need to be improved: (1) the carbon stocks in living biomass of the shrub, rattan and grass planted on GGP-lands; (2) the carbon stocks in dead organic matter (including litter and dead wood); (3) the carbon stock in the harvest wood products; and (4) factors for the changes in soil organic carbon.

\section{Acknowledgements}

We would like to give our appreciation to China Ministry of Science and Technology for its financial support under the project No. 2002CB412508 and 2001-BA611B-04, and to the GGP office of Yunnan Provincial Forestry Department for its data support.

\section{References}

Bateman, I.J., Lovett, A.A., 2000. Estimating and valuing the carbon sequestered in softwood and hardwood trees, timber products and forest soil in Wales. J. Environ. Manage. 60, 301-323.

Birdsey, R.A., Plantinga, A.S., 1993. Past and prospective carbon storage in United States. For. Ecol. Manage. 58, 33-40.

Cao, J., Zhang, Z.L., Liu, Y.H., 2002. The carbon stocks change of the forest ecosystem in Hainan Island in the past two decades. Geogr. Res. 21 (5), 551-560.

Chen, J.J., 2002. Practical manual of forestry ecological restoration and water and soil conservation through Grain for Green. World Electronic Medium Press, Beijing, pp. 174, 253-379.

Central-South Center for Monitoring Forest Resources of State Forestry Administration (CSIMFR), Yunnan Provincial Forestry Department (YPFD), 2003. Outcome of fourth verification on continuous forest resources inventory in Yunnan Province, pp. 63-69 (unpublished).

CSIMFR, YPFD, 1998. Outcome of third verification on continuous forest resources inventory in Yunnan Province, pp.63-69 (unpublished)

CSIMFR, YPFD, 1993. Outcome of second verification on continuous forest resources inventory in Yunnan Province, pp. 55-64 (unpublished).

Dixon, R.K., Brown, S., Houghion, R.A., et al., 1994. Carbon pools and flux of global forest ecosystems. Science 263, 185-190.

Fang, J.Y., Chen, A.P., Peng, C.G., Zhao, S.Q., Ci, L.J., 2001. Changes in forest biomass carbon storage in China between 1949 and 1998. Science 292, 2320-2322.

Institute of Forest Ecology, Environment and Protection CAF (IFEEP), 2004. Checklist Report of land-use change and forestry greenhouse gas emission in China, pp. 30-49.

Grigal, D.F., Ohmann, L.F., 1992. Carbon storage in upland forests of the lake states. Soil Sci. Soc.Am. J. 56, 935-943.

IPCC, 2000. Land use, land-use change and forestry. http://www.grida.no/climate/ ipcc/land-use/

Jiao, Y., Hu, H.Q., 2005. Carbon storage and its dynamics of forest vegetations in Heilongjiang province. Chin. J. Appl. Ecol. 16 (12), 2248-2252.

Lazams, M., Kartha, S., Bernow, S., 2001. Project baselines and boundaries for project-based GHG emission reduction trading. A report to the greenhouse gas emission trading pilot project. Boston. http://www.tellus.org.

Li, S.D., 2004. Research on the Grain for Green in China. Science Press, Beijing, pp. 5, 26-29, 110-111, 137-140, 190-222, 295-296.

Like, R., Wang, S.Q., Zhao, S.D., 2000. Carbon storage in China's vegetation and soils. Sci. China (Series D) 33 (1), 72-80.

Liu, H., Lei, R.D., 2005. Research methods and advances of the carbon storage and balance in forest ecosystems of China. J. Northwest Bot. 25 (4), 835-843.

Niu, X.Z., Duiker, S.W., 2006. Carbon sequestration potential by afforestation of marginal agricultural land in the Midwestern U.S. For. Ecol. Manage. 223, 415-427. 
Paul, K.I., Polglase, P.J., Nyakuengama, J.G., Khanna, P.K., 2002. Change in soil carbon following afforestation. For. Ecol. Manage. 168, 241-257.

Paul, K.I., Polglase, P.J., Ricards, G.P., 2003. Predicted change in soil carbon following afforestation or reforestation, and analysis of controlling factors by linking a C accounting modal (CAMFor) to modals of forest growth (3PG), litter decomposition (GENDEC) and soil C turnover (RothC). For. Ecol. Manage 177, 485-501.

Post, W.M., Kwon, K.C., 2000. Soil carbon sequestration and land-use change: processes and potential. Glob. Change Boil 6, 317-327.

Research Group of China Forestry Sustainable Development Strategy (RGCFSDS), 2002. Research on China Forestry Sustainable Development Strategy. China Forestry Publishing House, Beijing, pp. 135-177.

State Council of the People's Republic of China (SCPRC), 2002. Regulations for the Grain for Green (official document)

SFAPRC, 2001. The Compilation of National Technical Standards for Cultivating Forest (afforestation management roll). China Standard Press, Beijing, pp. 133-134.

Skog, K.E., Nicholson, G.A., 2000. Carbon sequestration in wood and paper products Gen. Tech. Re RMRS-GTR-59. In: USDA Forest Service.
UNFCCC, 2001. The Marrakesh accords and the Marrakash declaration, Version: 1011-01.2001.

UNFCCC, 2003 Modalities and procedures for afforestation and reforestation project activities under the clean development mechanism in the first commitment period of the KyotoProtocol. [EB/OL]. [2004-03-03]. http://unfccc.int/resource/ docs/cop9/06a02.pdf.

Wang, X.K., Feng, Z.W., Ouyang, Z.Y., 2001. The impact of human disturbance on vegetative carbon storage in forest ecosystems in China. For. Ecol. Manage. 148 117-123.

Willems, S., 2000. Framework for baseline guidelines. http://www.oecd.org/env/d ocs/cc/baseline-framework.pdf.

Zhang, D.Q., Sang, W.G., Li, R.F., 2002. Research on the forest organic carbon pool and its dynamics in Shandong province. J. Bot. Ecol. 26 (suppl.), 93-94.

Zhao, M., Zhou, G.S., 2004. Carbon storage of forest vegetation and its relationship with climatic factors. Acta Geogr. Sin. 24 (1), 50-54.

Zhou, Y.R., Yu, Z.L., Zhao, S.D., 2000. Carbon storage and budget of the major Chinese Forest Types. Acta Phytoecol. Sin. 24 (5), 518-522. 